\title{
THE FISH FAUNA OF EARLY-MEDIEVAL LAYERS OF THE VEGETABLE MARKET EXCA- VATION SITE IN SZCZECIN, POLAND
}

\author{
Zygmunt CHEŁKOWSKI ${ }^{1}$, Bernard KŁYSZEJKO ${ }^{1 *}$, Bożena CHEŁKOWSKA ${ }^{1}$, \\ Andrzej SOBOCINSSKI ${ }^{2}$ \\ ${ }^{1}$ Division of Fish Physiology, ${ }^{2}$ Division of Fish Anatomy and Embryology, \\ Agricultural University of Szczecin, Poland
}

Chełkowski Z., Kłyszejko B., Chełkowska B., Sobociński A., 2005. The fish fauna of early-medieval layers of the Vegetable Market excavation site in Szczecin, Poland. Acta Ichthyol. Piscat. 35 (1): 15-27.

Background. The more than 10-metre deep archaeological site called the Vegetable Market (Kraut Markt), located near the Pomeranian Dukes' Castle in Szczecin, was explored in 1953-1964. The site was found to contain 20 early-medieval sediment layers and a layer overlying the basement consisting of riverine mud. Historically, the layers spanned a period from the second decade of the 10th to the beginning of the 5th decade of the 13th century.

Materials and methods. The dig yielded numerous cultural artefacts, including fish remains examined during this study. The present paper summarises continuation of research on fish bone remains. The research allowed to identify a total of 10085 bones in 725 labelled collections. The identified bones of 20 fish species were compared with bones of the extant known fish species, belonging to individuals of various size. The analysis made it possible to estimate the lowest abundance and weight of the fish present at the archaeological site examined.

Results. The assemblage of 20 species, the remains of which were present in sediment of the site, turned out to be dominated, in terms of abundance, by carp bream (26.4\%), followed by zander $(17.5 \%)$, roach $(15,9 \%)$, tench $(9,5 \%)$, wels catfish $(9.6 \%)$, northern pike $(6.3 \%)$, European perch $(6.0 \%)$, sturgeon $(3.1 \%)$, and asp $(2.2 \%)$, the total fish weight being dominated by sturgeon $(31.3 \%)$, followed by wels catfish $(27.0 \%)$, zander $(15.3 \%)$, carp bream $(10.6 \%)$, northern pike $(5.1 \%)$, tench $(4.2 \%)$, roach $(2.2 \%)$, asp $(2.1 \%)$, and European perch $(1.1 \%)$. The remaining 11 species (twaite shad, European chub, ide, rudd, zope, white bream, Baltic vimba, ziege, crucian carp, European eel, and ruffe) contributed much less both to the abundance and to the weight.

Key words: archaeological excavations, early Middle Ages, fish remains

\section{INTRODUCTION}

The present paper is aimed characterising the fish species represented by bone remains found in earlymedieval sediment layers of the archaeological excavation site in Szczecin, known as the Vegetable Market (Kraut Markt). The dig is located in Szczecin, in the vicinity of the Pomeranian Dukes' Castle, on the left bank of the western branch of the Odra River. This paper summarises studies, carried out in continuation of earlier research during which the fish bones were identified anatomically and assigned to individual species (Kłyszejko et al. 2004). This part of the study involves a comparison between the identified bones from the archaeological site in question with bones of known fish species, yielded by individuals of various weight, occurring at present in the Odra estuary, i.e. in the area adjacent to the Vegetable Market.

The study's objective is to obtain insight into the size structure of the fish within individual species so that the amounts of fish consumed by inhabitants of the earlymedieval Szczecin can be estimated.

\section{MATERIALS AND METHODS}

The Vegetable Market archaeological excavation site covered $100 \mathrm{~m}^{2}$; the dig was deep enough (more than $10 \mathrm{~m}$ ) to reach the basement. The site revealed 29 early-medieval sediment layers (IV-XXXII) of a total thickness of $7.7 \mathrm{~m}$ as well as the oldest layer (XXXIII) overlying the basement and consisting of about 1-m thick riverine mud. The layers span a period starting from the second decade of the 10th century until the beginning of the 5th decade of the 13th century (Dworaczyk et al. 2003). The layers were found to contain numerous artefacts of material culture, including fish remains (Wieczorowski 1962, Wesołowski 1963, Leciejewicz et al. 1972, Rulewicz 1974, 1994).

During exploration of the site, carried out within 1953-1964 by the Polish Academy of Sciences' Archaeological Laboratory, Institute of Material Culture

\footnotetext{
* Correspondence: Dr hab. Bernard Kłyszejko, prof. nadzw., Zakład Fizjologii Ryb, Akademia Rolnicza w Szczecinie, ul. Kazimierza Królewicza 4, 71-550 Szczecin, Poland, e-mail: ber@fish.ar.szczecin.pl
} 
in Szczecin (at present Polish Academy of Sciences' Archaeological Laboratory of Institute of Archaeology and Ethnography in Szczecin), a collection of 725 labelled assemblages of fish bones was accumulated. All the assemblages contain more than 13200 fish bone remains, 10085 of which $(76.2 \%)$ were identified. The number of identified bones varied, depending on a layer, from 13 in layer IV to 1934 in layer VII; the number of fish species identified based on the bones ranged from 5 in layer IV to 16 in layer VII (Table 1). All the fish bones identified in the Vegetable Market sediment layers were left by 20 fish species; the number of bones left by individual species varied from 1 bone left by ziege to 3297 bones left by carp bream (Table 2) (Kłyszejko et al. 2004).

Comparative analyses of bone remains retrieved from the Vegetable Market early-medieval layers were carried out within individual assemblages. Subsequently, the data from individual layers and from the entire dig were pooled and analysed in their entirety.

This paper compares the fish bones identified earlier (Kłyszejko et al. 2004) with a series of corresponding bone elements of the extant fish species represented by individuals differing in weight. That provided a basis on which to estimate the probable lowest quantity of fish represented by the fish bone collection, individual weight of the fishes, and the total weight of each species represented in the collection (Kaj 1957, Makowiecki 1993, 2003, Marciniak 1996, Chełkowski et al. 1998, 2001, Filipiak and Chełkowski 2000).

To estimate the abundance and weight of the sturgeon the remains of which were present in the collection analysed, three specimens of the species kept in museums were used. Two of those specimens, weighing 60 and 136 $\mathrm{kg}$, are kept at the Faculty of Food Sciences and Fisheries, Agricultural University of Szczecin, the third specimen (84 kg individual weight) being displayed by the Fisheries Museum in Świnoujście. The abundance and weight of the remaining fish species were estimated based on skeletal bones of fish differing in individual weights. Bone sizes of fish of known weight were compared with the identified bones found in the dig; the results were interpolated to estimate the quantity and mass of fish in the Vegetable Market. By way of example, comparisons of the cleithrum from the left shoulder of wels catfish (Fig. 1) and of the preopercular bones of the left part of the viscerocranium of zander (Fig. 2) are described in detail.

Summary of research materials retrieved from the Vegetable Market

Table 1

\begin{tabular}{|c|c|c|c|c|}
\hline $\begin{array}{l}\text { Item } \\
\text { No. }\end{array}$ & Layer & $\begin{array}{c}\text { Number of bone } \\
\text { assemblages }\end{array}$ & $\begin{array}{c}\text { Number of bones } \\
\text { identified }\end{array}$ & $\begin{array}{c}\text { Number of fish } \\
\text { species }\end{array}$ \\
\hline 1 & IV & 5 & 13 & 5 \\
\hline 2 & V & 7 & 73 & 10 \\
\hline 3 & VI & 4 & 22 & 6 \\
\hline 4 & VII & 83 & 1934 & 16 \\
\hline 5 & VIII & 43 & 379 & 11 \\
\hline 6 & IX & 31 & 224 & 13 \\
\hline 7 & $\mathrm{X}$ & 44 & 529 & 12 \\
\hline 8 & XI & 13 & 240 & 11 \\
\hline 9 & XII & 13 & 83 & 11 \\
\hline 10 & XIII & 16 & 180 & 10 \\
\hline 11 & XIV & 13 & 134 & 9 \\
\hline 12 & $X V$ & 19 & 112 & 11 \\
\hline 13 & XVI & 17 & 283 & 13 \\
\hline 14 & XVII & 12 & 229 & 9 \\
\hline 15 & XVIII & 14 & 934 & 10 \\
\hline 16 & XIX & 16 & 979 & 15 \\
\hline 17 & $X X$ & 15 & 259 & 11 \\
\hline 18 & XXI & 53 & 657 & 12 \\
\hline 19 & XXII & 22 & 271 & 14 \\
\hline 20 & XXIII & 9 & 120 & 11 \\
\hline 21 & XXIV & 55 & 439 & 13 \\
\hline 22 & XXV & 16 & 60 & 9 \\
\hline 23 & XXVI & 35 & 136 & 10 \\
\hline 24 & XXVII & 7 & 30 & 7 \\
\hline 25 & XXVIII & 51 & 488 & 14 \\
\hline 26 & XXIX & 26 & 653 & 15 \\
\hline 27 & XXX & 9 & 90 & 10 \\
\hline 28 & XXXI & 34 & 302 & 13 \\
\hline 29 & XXXII & 34 & 213 & 13 \\
\hline 30 & XXXIII & 9 & 19 & 6 \\
\hline & Total & 725 & 10085 & 20 \\
\hline
\end{tabular}


Number of identified bones, retrieved from early-medieval Vegetable Market layers,

Table 2 assigned to individual fish species

\begin{tabular}{rlr}
\hline No. & \multicolumn{1}{c}{ Species } & $\begin{array}{c}\text { Number of bone } \\
\text { remains }\end{array}$ \\
\hline 1 & Acipenser sturio L., sturgeon & 308 \\
2 & Alosa fallax (Lacepède, 1803), twaite shad & 2 \\
3 & Esox lucius L., northern pike & 475 \\
4 & Abramis ballerus (L.), zope & 49 \\
5 & Abramis brama (L.), carp bream & 3297 \\
6 & Aspius aspius (L.), asp & 190 \\
7 & Blicca bjoerkna (L.), white bream & 4 \\
8 & Carassius carassius (L.), crucian carp & 21 \\
9 & Leuciscus cephalus (L.), European chub & 18 \\
10 & Leuciscus idus (L.), ide & 45 \\
11 & Pelecus cultratus (L.), ziege & 1 \\
12 & Rutilus rutilus (L.), roach & 1308 \\
13 & Scardinius erytrophthalmus (L.), rudd & 13 \\
14 & Tinca tinca (L.), tench & 858 \\
15 & Vimba vimba (L.), Baltic vimba & 8 \\
16 & Silurus glanis L., wels catfish & 769 \\
17 & Anguilla anguilla (L.), European eel & 66 \\
18 & Gymnocephalus cernuus (L.), ruffe & 5 \\
19 & Perca fluviatilis L., European perch & 498 \\
20 & Sander lucioperca (L.), zander & 2150 \\
\hline & Total & 10085 \\
\hline
\end{tabular}

The comparative analyses of fish bones or other bone remains, e.g. bony plates of the sturgeon, retrieved from the Vegetable Market early-medieval layers, were aided by the following publications: Suworow (1954), Lebedev (1960), Urbanowicz (1965), Ninua (1976), Desse et al. (1987), Rolik and Rembiszewski (1987), Baruš and Oliva (1995), Hochleithner (1996), Kottelat (1997), Kolman (1999), and Brylińska (2000).

An example of a comparative analysis

The analyses carried out during the first stage of the research (Kłyszejko et al. 2004) showed the Vegetable Market layer IV to have supplied 5 labelled bone assemblages with 13 identified bone remains from 5 fish species (Table 1). Table 3 summarises the results of the comparative analysis. The first assemblage from layer IV contained the tench cleithrum left by a specimen the weight of which was estimated at $1.3 \mathrm{~kg}$. The second assemblage contained 2 bones of zander: the articular bone and the preopercular one, left by a specimen the weight of which was estimated at about $1.0 \mathrm{~kg}$. The third assemblage contained 2 bones of northern pike: the cleithrum and the maxilla from 2 specimens of weights estimated at 2.0 and $5.5 \mathrm{~kg}$; the assemblage contained also the cleithrum of a carp bream specimen weighing about $1.5 \mathrm{~kg}$, a pectoral fin ray of an about $4.0 \mathrm{~kg}$ wels catfish specimen, and the parasphenoid bone of an about $3.5 \mathrm{~kg}$ zander individual. The fourth assemblage revealed 1 vertebra of an about 6.0 $\mathrm{kg}$ northern pike as well as the ceratohyale, parasphenoid, and a vertebra left by 3 zander individuals weighing about $1.3,2.0$, and $3.0 \mathrm{~kg}$, respectively. In the fifth assemblage, it was only the palatine bone that was identified as having been left by a wels catfish specimen the weight of which was estimated at $25 \mathrm{~kg}$.

As shown by the layer IV data, northern pike remains were present in 2 assemblages and consisted of 3 bones left by 3 specimens of a total weight estimated at about $13.5 \mathrm{~kg}$. The tench remains consisted of 1 bone left by an about $1.25 \mathrm{~kg}$ specimen. The carp bream remains consisted, too, of a single bone left by an about $1.5 \mathrm{~kg}$ individual. The wels catfish remains, in the form of single bones, occurred-one each-in 2 bone assemblages and were left by 2 specimens of a total weight estimated at $29 \mathrm{~kg}$. Zander remains were identified in 3 assemblages and consisted of 6 bones left by 5 specimens weighing from 1.0 to $3.5 \mathrm{~kg}$ (total weight of $10.8 \mathrm{~kg}$ ). To sum up, a total of 13 bones identified in the Vegetable Market layer IV was left by 12 fish specimens of a total weight of $56 \mathrm{~kg}$.

\section{RESULTS}

Comparisons between bones present in the archaeological collection and those belonging to contemporary fish individuals of different weight made it possible to estimate the abundance and weight of the fish the remains of which had been left at the site. Results, broken down by species, are shown in Table 4.

One of the objectives of the comparative analysis was to determine the abundance (number of individuals) of fish based on the identified bones found in different earlymedieval layers of the Vegetable Market. The entire collection of 10085 identified bones (Tables 1,2) allowed to estimate that they had been left by 5530 fish individuals 


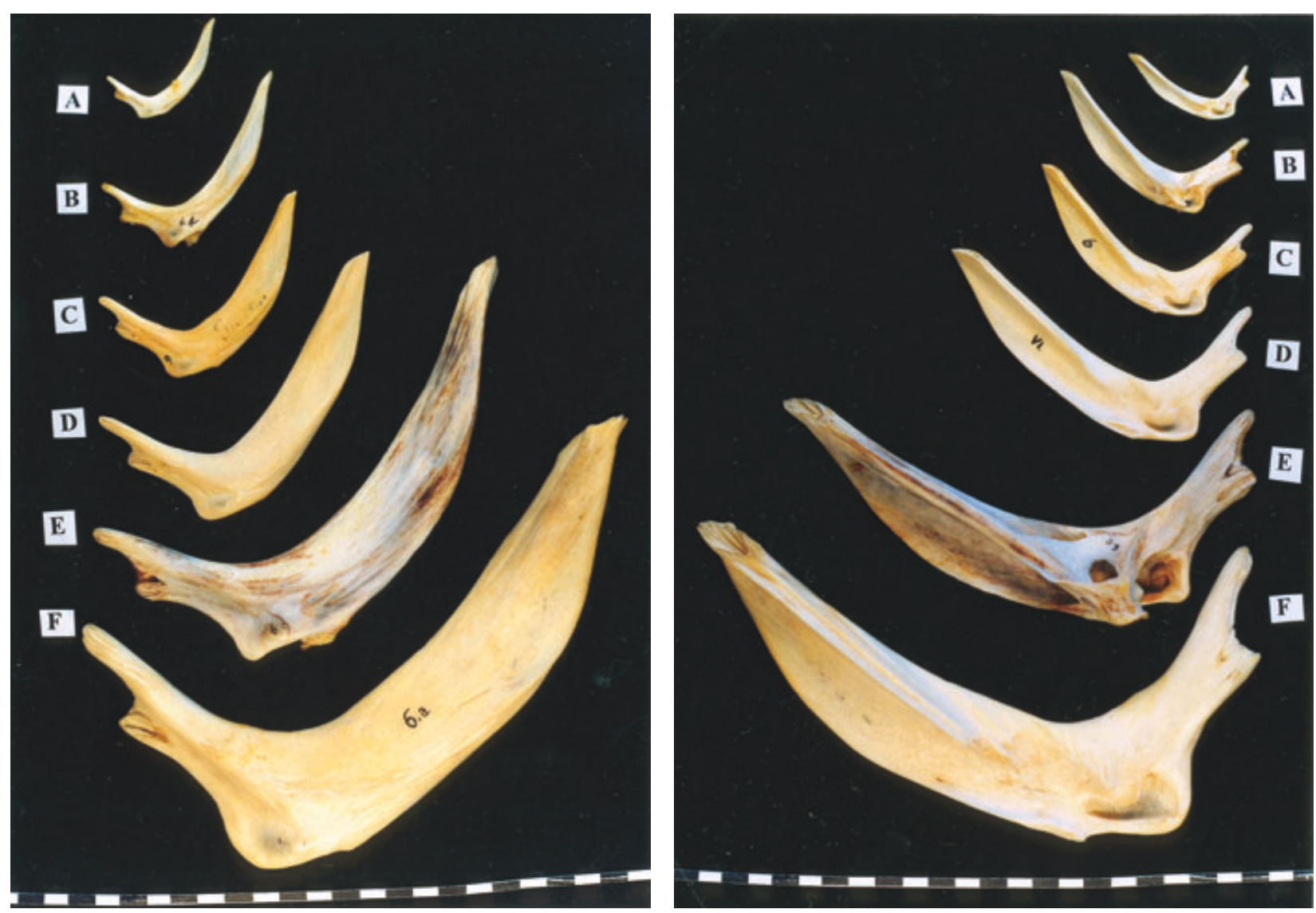

Fig. 1. Comparative materials: left cleithrum bones of the European wels catfish, Silurus glanis L., individuals weighing: A, $0.40 \mathrm{~kg}$; B, $1.19 \mathrm{~kg}$; C, $2.57 \mathrm{~kg}$; D, $5.10 \mathrm{~kg}$; E, $21.10 \mathrm{~kg} ; \mathrm{F}, 32.30 \mathrm{~kg}$ (outer- and inner view)
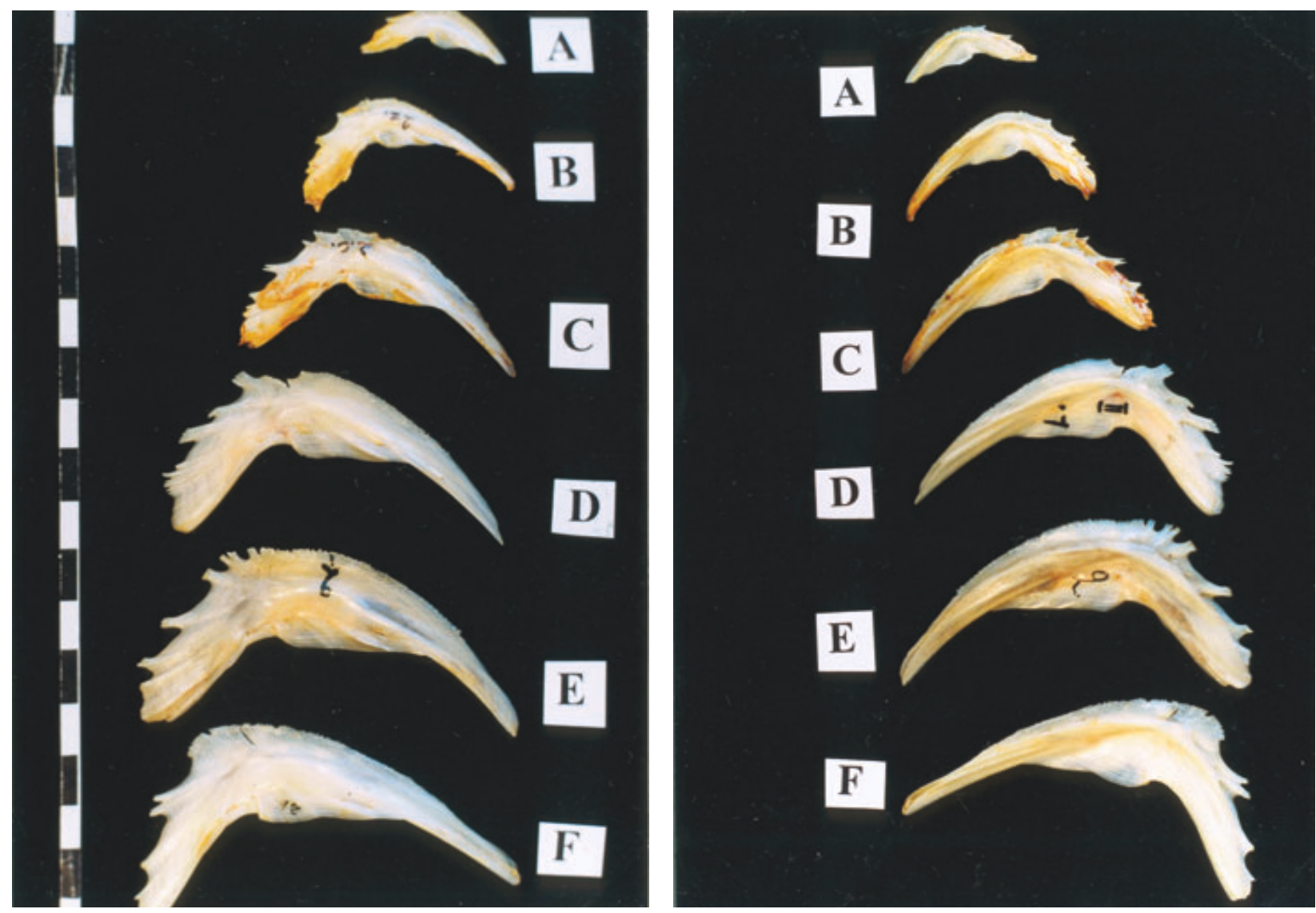

Fig. 2. Comparative materials: left preopercular bones of the zander, Sander lucioperca (L.), individuals weighing: A, $0.46 \mathrm{~kg}$; B, $0.80 \mathrm{~kg}$;, $1.86 \mathrm{~kg} ; \mathrm{D}, 3.01 \mathrm{~kg} ; \mathrm{E}, 4.96 \mathrm{~kg} ; \mathrm{F}, 6.20 \mathrm{~kg}$ (outer- and inner view) 
$\frac{9}{2}$

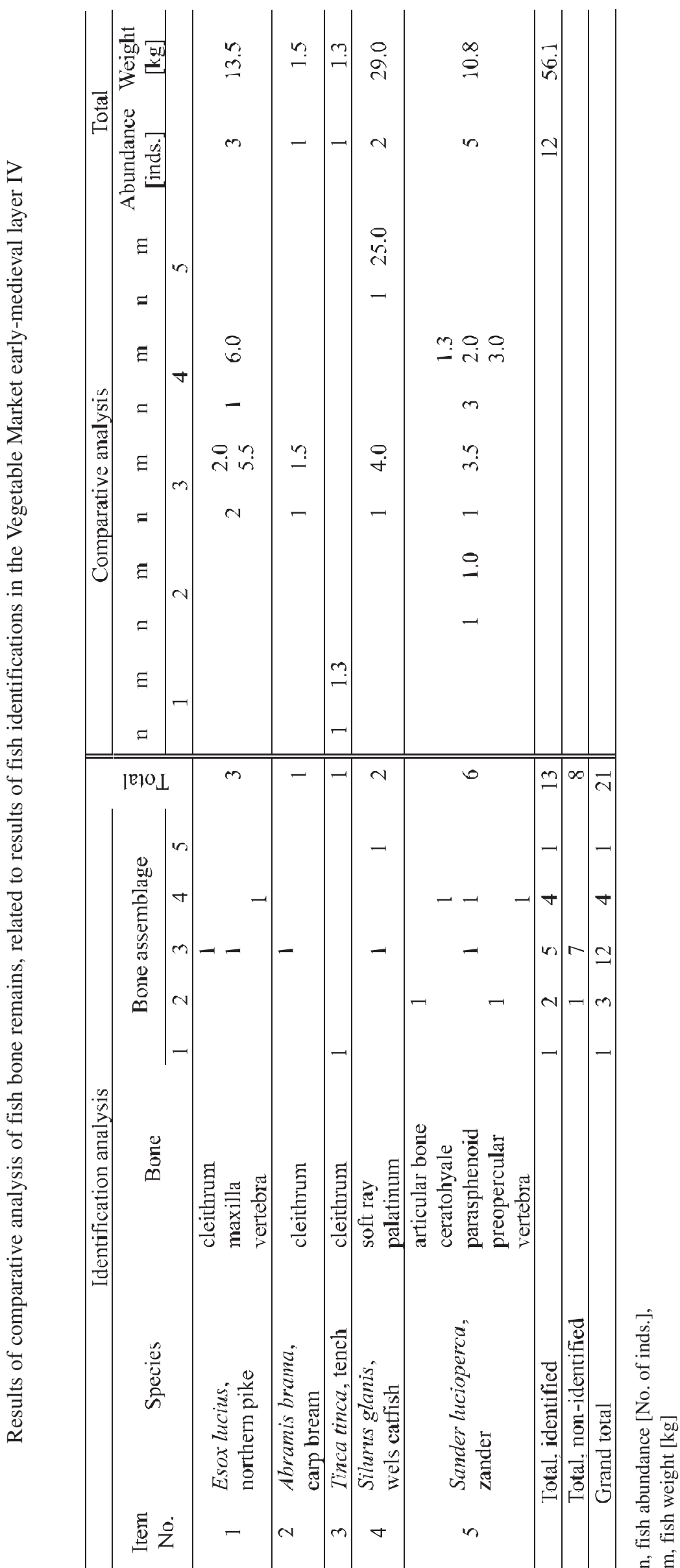


$\frac{+}{\frac{0}{6}}$

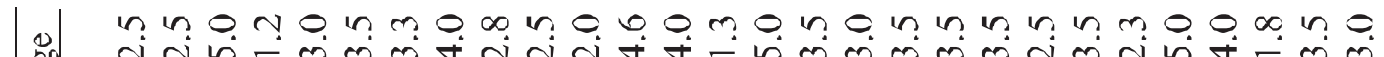

ज र

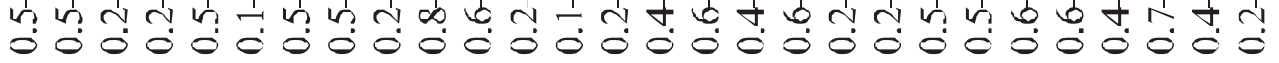

- $\quad$ 뜨

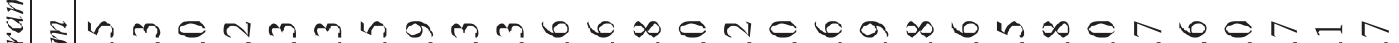

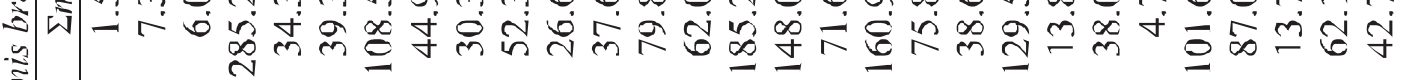

政

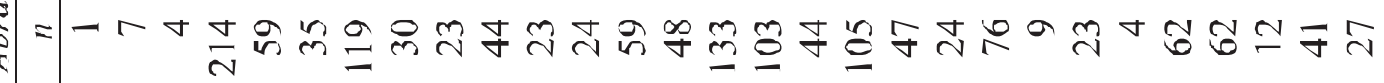

+

草市

实

a 0 d

$\begin{array}{ll}0 & m \\ 0 & 0 \\ 0 & 0\end{array}$

ㅁ.

ㄴ.

-

i

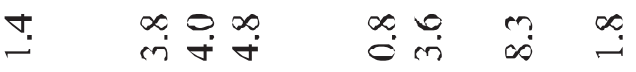

N

o thin $-m$ N

N

- 0.0 . 0.0 in 0

on

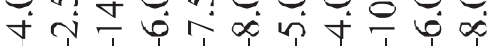

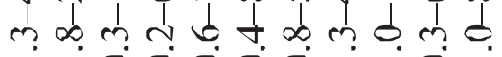
m $\infty \propto+\infty d \infty$ ठ்

- - $000001-0$.

n 0 \%

m-ogra -0 m n

ขั่ง

mก ก ข ๙ூ nontaNNm-m

$$
\text { N }
$$

$m \oslash \underset{c}{m}=$

$\mathrm{N} \odot$

\section{$00 \infty \stackrel{0}{0} 0$} $\infty$ v $\infty \mathrm{m} b$ oं $0 \dot{0} 0$.

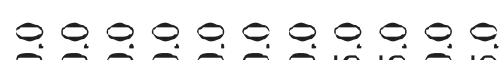
군ํำ

1 010 d 0 o 0 in 0 o 0. 긍ำำ ำกำ

n n - n no ம

* ono o o o o o o o.0. ชู nn

t

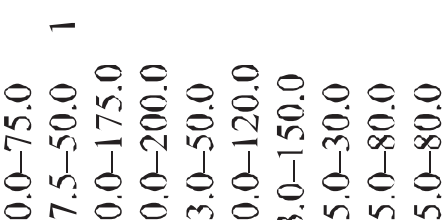

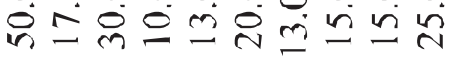

늠

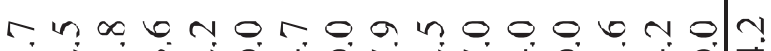
-

o r o o o o o o o o o o o o o o.

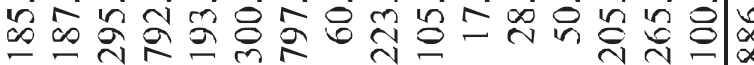




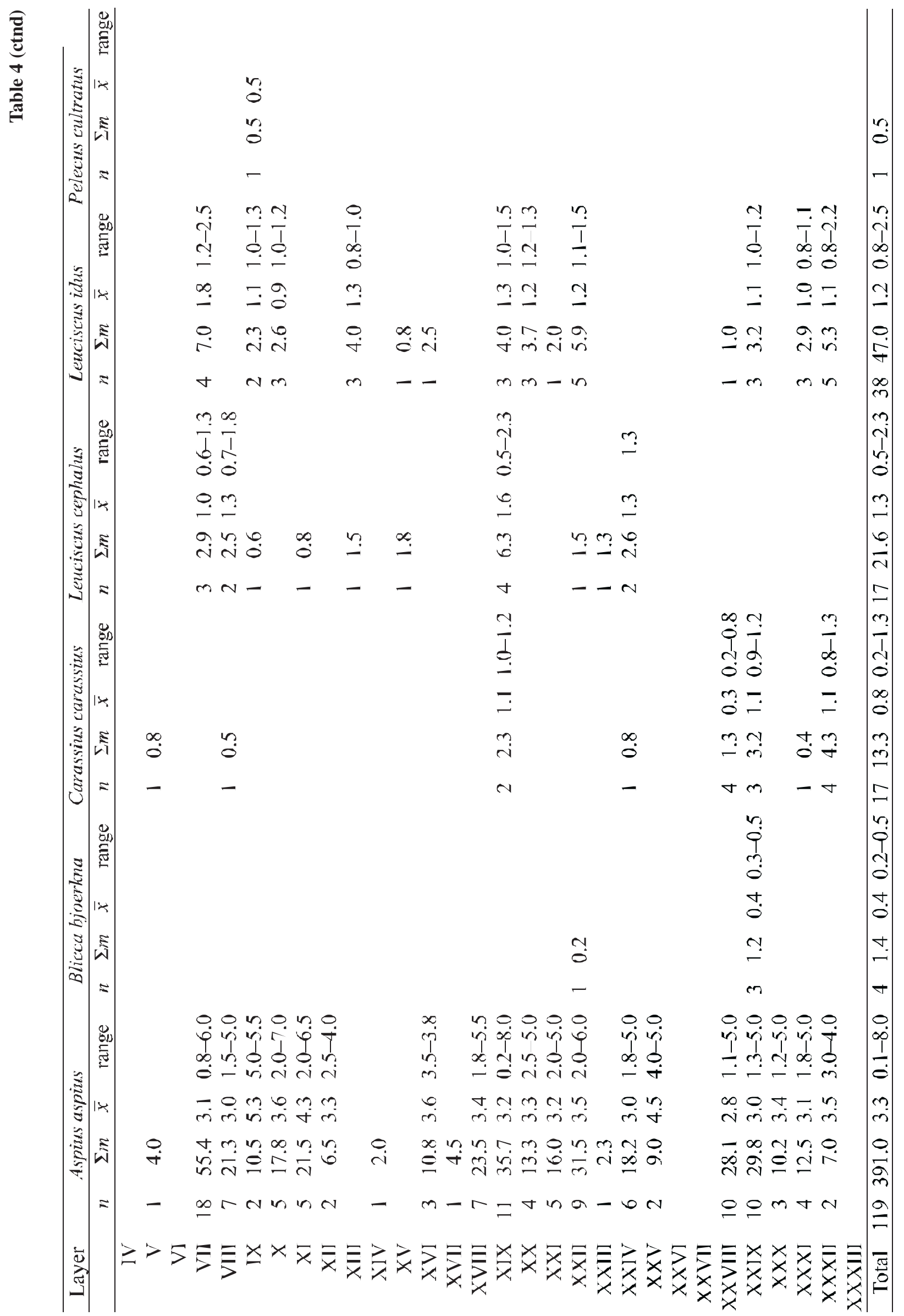




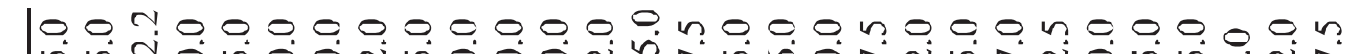
แñ

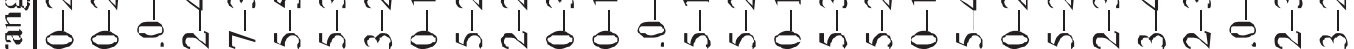

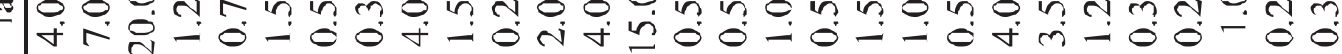
IN

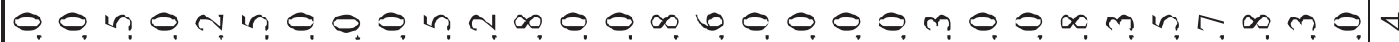
ฟิํํㅇ

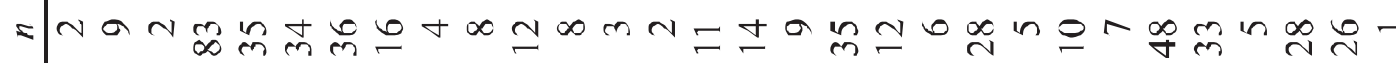

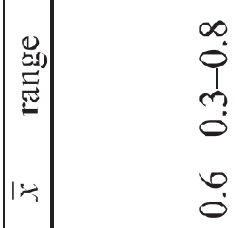

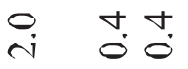

m

ฟ

ণi

i.

$=m$

$-\quad-$

N

$\stackrel{+}{i}$

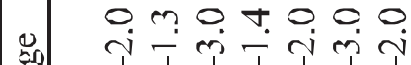

o. no n

-

(1)

E్t:

montonn

1)

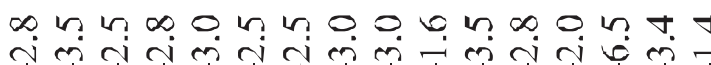

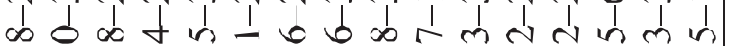

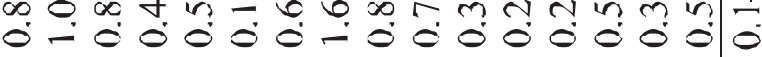

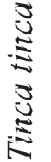

- ícó 0

0

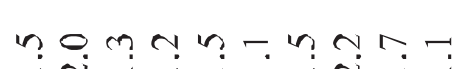

? ? †

m n m $\infty$ on $\infty$ m m m

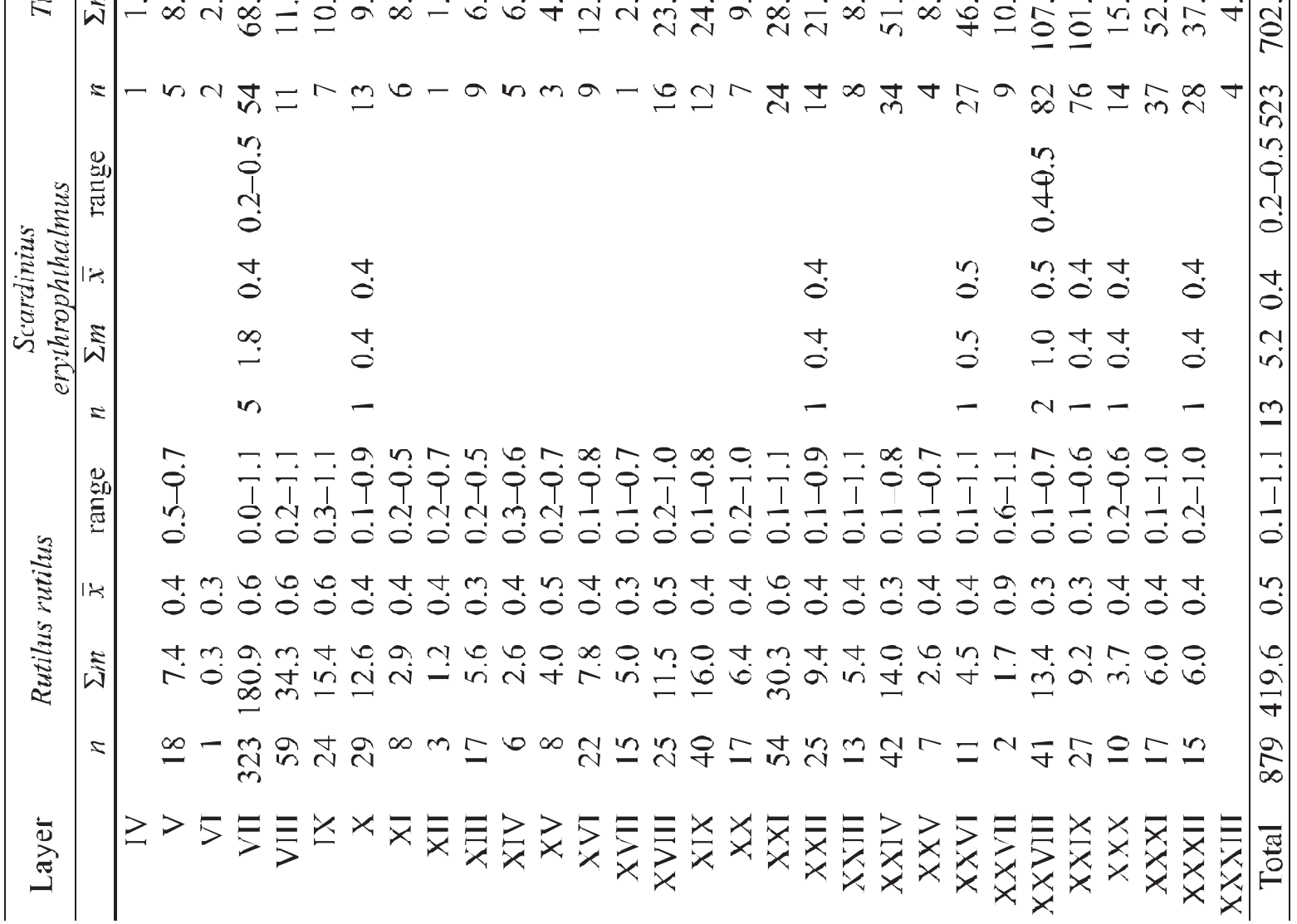




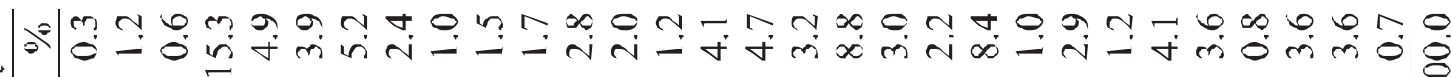

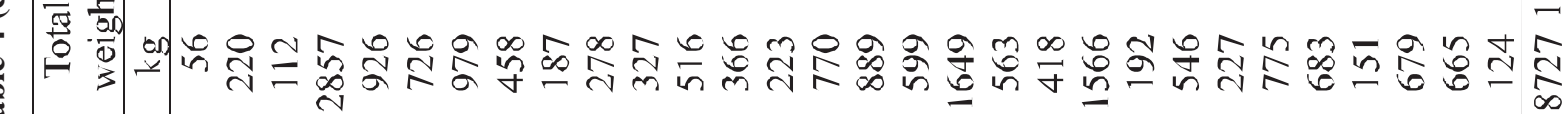

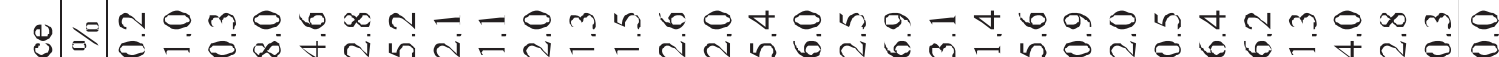

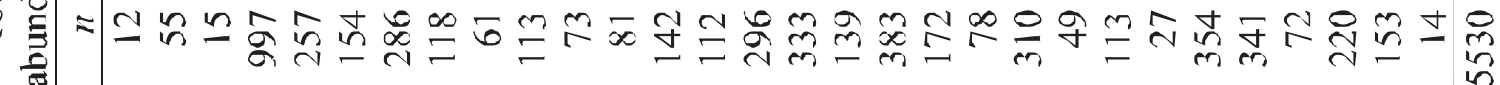

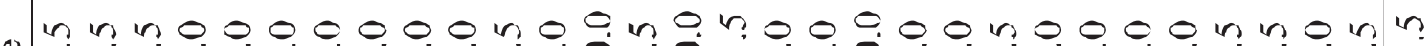
का

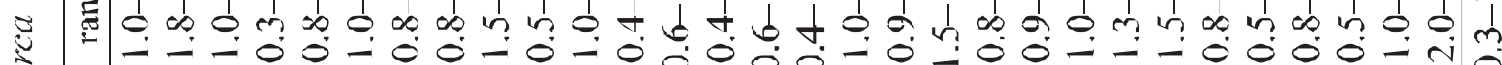
¿

,

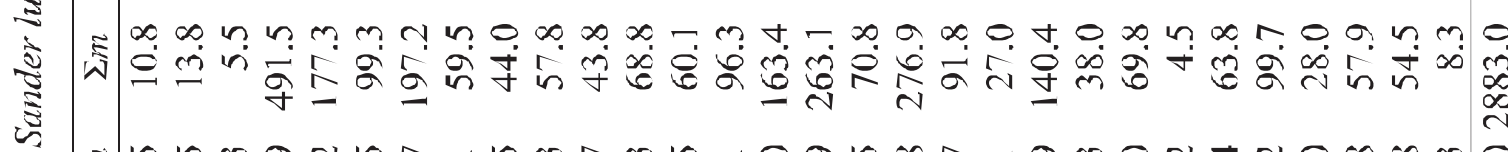
ㄸ ๓

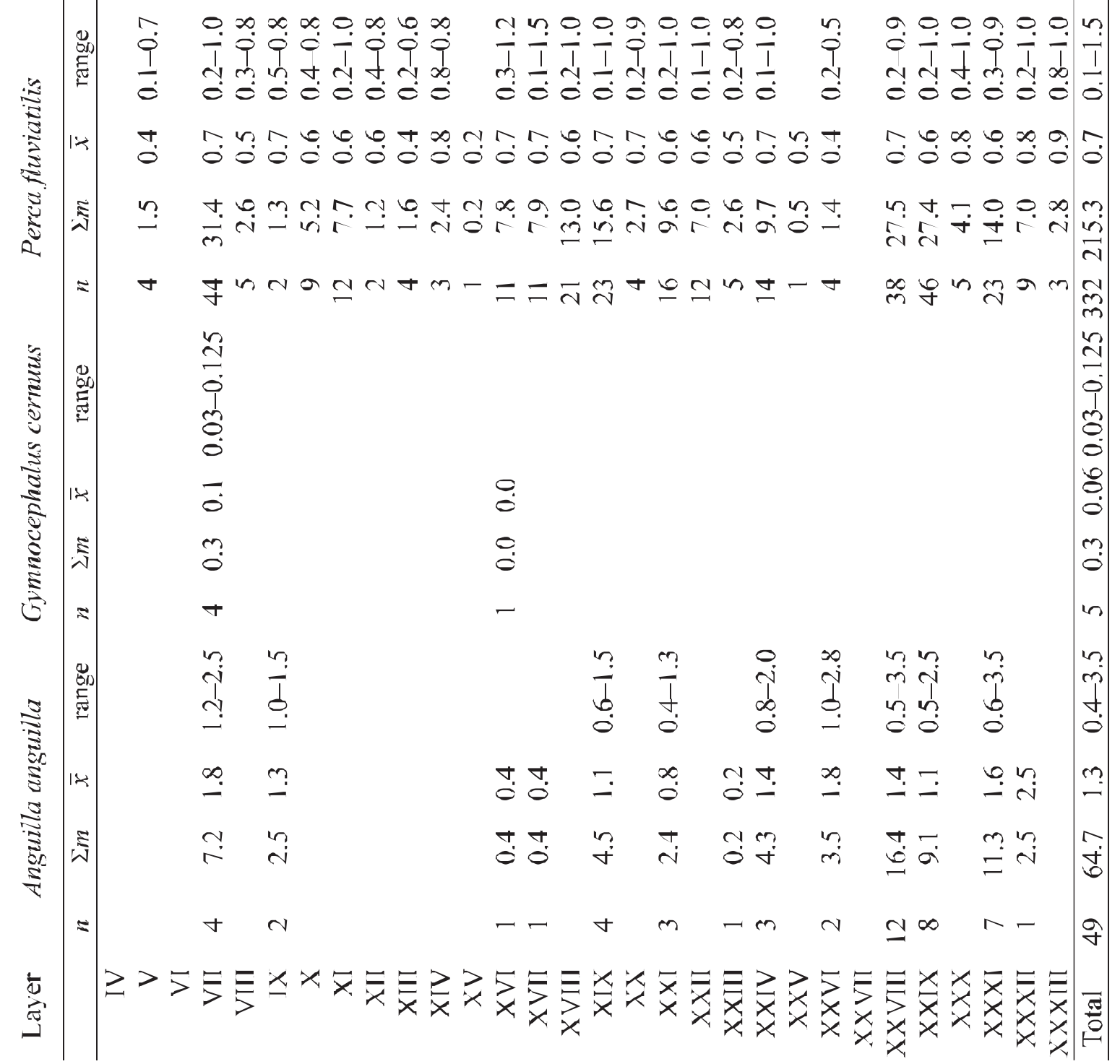




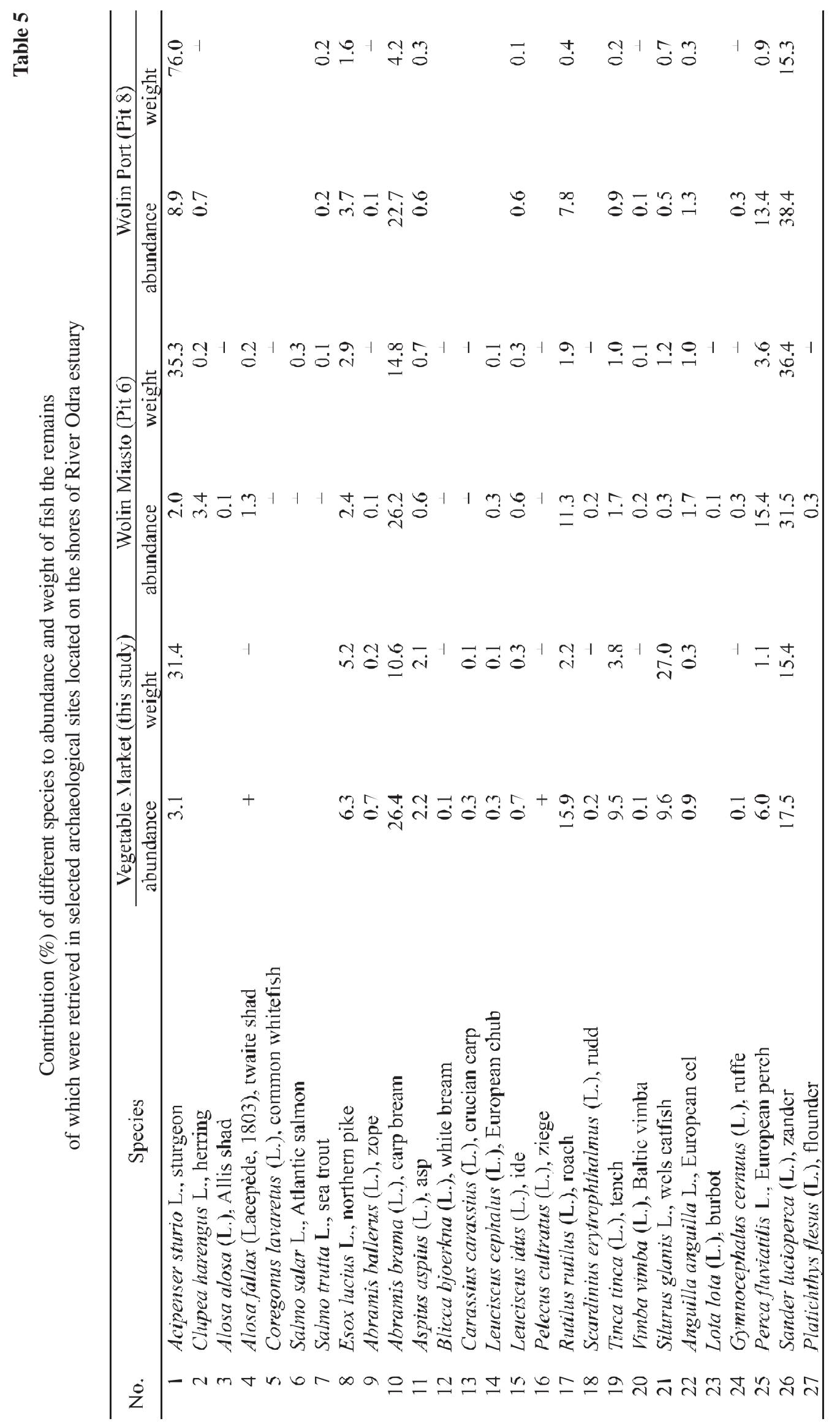




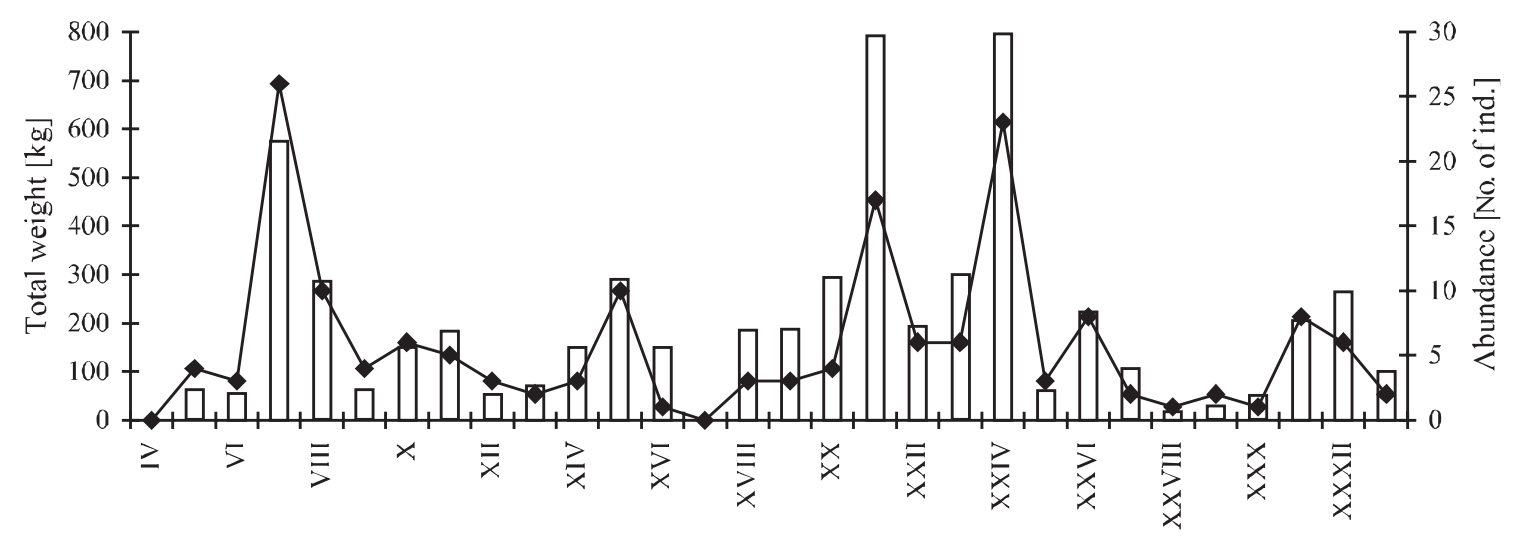

Layers

\footnotetext{
$\square$ Total weight $\neg$ Abundance
}

Fig. 3. Frequency of occurrence of the sturgeon, Acipenser sturio L., and its estimated total weight in the early-medieval deposit layers of the Vegetable Market (total weight in $\mathrm{kg}$; abundance in number of individuals)

(Table 4). The highest number of individuals was present in layer VII: the estimated 997 individuals belonging to 16 species included 323 specimens of roach, 214 carp bream, 169 zander, 83 wels catfish, 54 tench, 44 European perch, 37 northern pike, 23 sturgeon, and lower quantities of other species. The remaining layers contained remnants of 12 (layer IV) to 383 (layer XXI) fish specimens.

The respective contributions of individual fish species occurring in all the Vegetable Market early-medieval layers showed European perch, zander, and roach to be the dominant species, contributing 26.4, 17.5, and $15.9 \%$, respectively. Wels catfish, tench, northern pike, and European perch contributed substantially as well: 9.6, 9.5, 6.3 , and $6.0 \%$, respectively. The contributions of sturgeon $(3.1 \%)$ and asp $(2.2 \%)$ were much lower. The remaining 11 fish species occurred sporadically (contributions not exceeding 1\%) (Table 5).

In addition to the abundance, the weight of the fish was estimated as well. The total weight of the fish that had left identifiable bones at the site amounted to about 18700 $\mathrm{kg}$. Like in the abundance, layer VII contributed most (15.2\%) to that weight, followed by layers XXI $(8.8 \%)$ and XXIV (8.3\%). Contributions of the remaining 27 layers were much lower and ranged from $0.3 \%$ in layer IV to $5.7 \%$ in layer X (Table 4).

Analysis of the partitioning of the total fish weight between individual species showed the highest contribution $(31.3 \%)$ to be that of sturgeon, followed by wels catfish $(27.0 \%)$, zander $(15.3 \%)$, and carp bream (10.6\%). Contributions of the following five species were much lower: $5.2 \%$ supplied by the northern pike, $4.2 \%$ by tench, $2.2 \%$ by roach, $2.1 \%$ by asp, and $1.1 \%$ by European perch. The remaining 11 species contributed less than $1 \%$ each (Table 5).

The sturgeon remains occurred in 28 early-medieval Vegetable Market layers. A total of 308 remains of the species was identified (Table 2). They were estimated to have belonged to 172 individuals the weight of which ranged from 10 to $200 \mathrm{~kg}$; the total sturgeon weight was assessed at about $5886 \mathrm{~kg}$. The abundance and weight of sturgeon differed widely between the layers, from single individuals present in layers XVI, XXVIII, and XXX to 26 in layer VII. Sturgeon was abundant also in layers XXIV (23 individuals) and XXI (17 individuals) as well as VIII and XV (10 individuals each). The total weight was at its highest in the following three layers: XXIV (about $800 \mathrm{~kg}$ ), XXI (about $790 \mathrm{~kg}$ ), and VII (about 570 $\mathrm{kg}$ ). In the remaining layers, the sturgeon weight was estimated to have varied from $17 \mathrm{~kg}$ in layer XXVIII to about $300 \mathrm{~kg}$ in layer XXIII (Fig. 3).

As concluded from analysis of the bones identified, individual early-medieval sediment layers differed widely in terms of both the abundance of fish and in individual and total weights of various species (Table 5).

\section{DISCUSSION}

In this study, comparative analyses of fish bone remains retrieved from the Vegetable Market earlymedieval layers allowed to estimate the abundance and weight of the fish. Similar studies on numerous bone remains collected from early-medieval sediment layers were carried out by Chełkowski et al. $(1998,2001)$ and by Filipiak and Chełkowski (2000) in the Odra River estuary shores at Wolin Port (Pit 8) and Wolin Miasto (Pit 6). While the Vegetable Market layers showed the highest contribution to be that of carp bream $(26.4 \%)$, followed by zander $(17.5 \%)$ and roach $(15.9 \%)$, the Wolin Port remains were dominated by those of zander $(38.4 \%)$, carp bream (22.7\%), and European perch (15.4\%); zander $(31.5 \%)$, carp bream $(26.2 \%)$, and European perch $(13.4 \%)$, too, were dominant in the Wolin Miasto pit (Table 5). Sturgeon contributed $9.0 \%$ in Wolin's Pit 8 , $3.1 \%$ in the Vegetable Market, and 2.0\% in Wolin's Pit 6.

Of the three sites compared for northern pike occurrence, the highest contribution was that in the Vegetable Market material (6.3\%),the contributions from Wolin's Pit $8(3.7 \%)$ and Wolin's Pit 6 (2.4\%) being lower. Roach con- 
tributed most to the Vegetable Market fish finds (11.3\%), the respective contributions to the Wolin's Pit 6 and Pit 8 being lower (11.3 and $7.8 \%$ ). The highest tench contribution was recorded in the Vegetable Market, much lower contributions being those in Wolin's Pit 6 and Pit 8 (1.7 and $0.9 \%$, respectively). The wels catfish contributed most to the Vegetable Market fish (9.6\%), compared to much lower contributions in Wolin: $0.5 \%$ in Pit 8 and $0.3 \%$ in Pit 6 . The European perch contributed most to the materials of the Wolin Miasto site (15.4\%) and to those of Wolin Port (13.4\%), much lower contribution being that found in the Vegetable Market $(6.0 \%)$. The contribution of asp was at its highest in the Vegetable Market $(2.2 \%)$, the species contributing much less to the materials from Wolin $(0.6 \%$ at each site). European eel was most abundantly represented in Wolin Miasto (1.7\%) and Wolin Port (1.3\%), the lowest contribution being that in the Vegetable Market dig (0.9\%).

The materials retrieved from the Vegetable Market early-medieval layers lacked remains of 6 species (herring, trout, salmon, whitefish, burbot, and flounder) that were present in the Wolin Miasto pit.

Despite the visible quantitative differences among the sites compared, the highest contributions among the cyprinids were those of carp bream (22.7-26.4\%), roach $(7.8-15.9 \%)$, and tench $(0.9-9.5 \%)$, while zander $(17.5-38.4 \%)$ and European perch $(6.0-15.4 \%)$ contributed most among the percids.

The estimated contribution of sturgeon to the total mass of fish that had left their remains in the Vegetable Market proved the highest $(31.3 \%)$, compared to contributions of the remaining species. Still higher was the sturgeon weight contribution at the Wolin Port site (76.0\%). At the Wolin Miasto site, the sturgeon-with its contribution of $35.3 \%$-was second to zander (36.4\%). Noteworthy weight contributions at the sites compared include those of zander (15.3-36.4\%), carp bream (4.2-14.8\%), northern pike (1.6-5.2\%), European perch (0.9-3.6\%), wels catfish $(0.7-27.0 \%)$, roach $(0.4-2.2 \%)$, asp $(0.3-2.1 \%)$, and tench $(0.2-4.2 \%)$. Weight contributions of the remaining species were much lower at all the sites (Table 5).

Sturgeon is a migratory (anadromous) species. Individual specimens may grow to $320 \mathrm{~kg}$ (Kolman 1999) or even to $600 \mathrm{~kg}$ (Hochleithner 1996). However, an average individual weight of harvested sturgeon ranges within $10-50 \mathrm{~kg}$. Based on the remains analysed, the sturgeon handled at the Vegetable Market site were estimated to weigh $10-200 \mathrm{~kg}$, the high mean individual weight providing evidence that it was mostly large specimens that had been caught.

Having grown out in the Baltic Sea, the sturgeon migrated upstream the Odra River system via its estuary; after spawning, the fish descended to the sea along the same route. The periods and routes of sturgeon migrations must have been known to the early-medieval settlers who harvested the fish and mastered the difficult art of sturgeon capture. Sturgeon was doubtless abundant in early Middle Ages and, when caught, was an economically valuable commodity.
The bone remains-based estimations of fish weights showed the bones to have been left by individuals of different sizes, from small (juvenile) to large (adult) (Table 4). For example, the estimated individual weights of roach varied from 0.02 to $1.1 \mathrm{~kg}$. The high mean individual weight of roach proves it was the larger roach that had been caught or, more plausibly, bones left by smaller fish had disintegrated (had been decomposed by mineralisation) and were not preserved in the collections (Marciniak 1996). However, the wide ranges of individual weights of the species harvested most frequently demonstrate that the early-medieval settlers used a diversity of fishing gear and techniques, as confirmed by the remains of various fishing gear found in the Vegetable Market layers (Rulewicz 1974, 1994). This is also indicated by the wreck of a large strake boat revealed on the bottom of layer XXXIII; according to Wieczorowski (1962), the boat was used in fishing operations.

\section{CONCLUSIONS}

Among the 20 fish species the remains of which occur in all the early-medieval layers of the Vegetable Market, those most abundant included carp bream (26.4\%), followed by zander $(17.5 \%)$, roach $(15.9 \%)$, wels catfish $(9.6 \%)$, tench $(9.5 \%)$, northern pike $(6.3 \%)$, European perch $(6.0 \%)$, sturgeon $(3.1 \%)$, and asp $(2.2 \%)$. In terms of the total species weight, the collection was dominated by sturgeon $(31.3 \%)$, followed by wels catfish $(27.0 \%)$, zander $(15.3 \%)$, carp bream $(10.6 \%)$, northern pike $(5.2 \%)$, tench $(4.2 \%)$, roach $(2.2 \%)$, asp $(2.1 \%)$, and European perch (1.1\%). Contributions of the remaining 11 fish species to both the abundance and total weight were much lower (less than 1\%).

The presence of as many as 20 fish species of an economic importance, represented by more than 5500 individuals of a total weight of $18800 \mathrm{~kg}$ demonstrates the importance of fisheries and fish in the diet of the inhabitants of early-medieval Szczecin.

The bones analysed showed a considerable variability in individual weights (from juvenile forms to adults) of the fish species represented, which could be taken as evidence that the fishermen used gear and techniques enabling them to harvest fish of a wide spectrum of sizes.

The presence of bone remains identified as belonging to 14 individuals of 6 species (of a total weight of about $125 \mathrm{~kg}$ ) in the oldest layer XXXIII as well as the remnants of a fishing boat in that layer demonstrate the importance of fisheries and the major role of fish in diets of the inhabitants of the area since the beginnings of human settlement there, i.e. the 2 nd decade of the 10 th century.

\section{ACKNOWLEDGEMENT}

This study was supported by the Polish Committee for Scientific Research (KBN) grant No. 2H01H 02324. 


\section{REFERENCES}

Baruš V., Oliva O., 1995. Mihulovci a ryby. [Cyclostomes and fishes.] Academia, Praha. (In Czech.)

Brylińska M., (ed.) 2000. Ryby słodkowodne Polski. [Freshwater fishes of Poland.] PWN, Warszawa. (In Polish.)

Chełkowski Z., Filipiak J., Chełkowska B., 1998. Występowanie i charakterystyka ichtiofauny we wczesnośredniowiecznych warstwach osadniczych portu w Wolinie. [Occurrence and description of fish remains in early medieval settlement layers of the port of Wolin.] Materiały Zachodniopomorskie 44: 223-246.

Chełkowski Z., Filipiak J., Chełkowska B., 2001. Studies on ichthyofauna from an archaeological excavation on Wolin-Town (site 1, pit 6). Acta Ichthyologica et Piscatoria 31 (1): 61-80.

Desse J., Desse-Berset N., Rocheteau M., 1987. Contribution a l'osteometrie de la perche (Perca fluviatilis Linné, 1758). Fiches d'ostéologie animale pour l'archéologie. Serie A. Poisson, No 1. ed. du Centre National de la Recherche Scientifique, Paris

Dworaczyk M., Kowalska A.B., Rulewicz M., 2003. Szczecin we wczesnym średniowieczu: wschodnia część suburbium. [Szczecin in early Middle Ages; eastern part of the suburbium.] Polskie Badania Archeologiczne T. 33, Instytut Archeologii i Etnologii PAN, Łódź. (In Polish.)

Filipiak J., Chełkowski Z., 2000. Ichtiofauna z wczesnośreniowiecznych warstw osadniczych Wolina (stanowisko 1, wykop 6). [The fish fauna of early-medieval sediment layers of Wolin (Site 1, pit 6).] Materiały Zachodniopomorskie 46: 213-234. (In Polish.)

Hochleithner M., 1996. Störe (Acipenseriformes): Verbreitung - Lebensweise - Aquakultur. Agrarverlag, Klosterneuburg.

Kaj J., 1957. Możliwości poznawcze badań ichtiologicznych w archeologii i metodyka badań. [Cognitive potential of ichthyological studies in archaeology; methodology.] Archeologia Polski 1: 116-125. (In Polish.)

Kłyszejko B., Chełkowski Z., Chełkowska B., Sobociński A., 2004. Identification of fish remains from early-medieval layers of the Vegetable Market excavation site in Szczecin. Acta Ichthyologica et Piscatoria 34 (1): 85-102.

Kolman R., 1999. Jesiotry. [The sturgeons.] Instytut Rybactwa Śródlądowego, Olsztyn. (In Polish.)

Kottelat M., 1997. European freshwater fishes. An heuristic checklist of the freshwater fishes of Europe (exclusive of former USSR), with an introduction for non-systematics and comments on nomenclature and conservation. Biologia $\mathbf{5 2}$ (suppl. 5): 1-271.

Lebedev V.D., 1960. Presnovodnaâ četvertičnaâ ihtiofauna evropejskoj časti SSSR. [Freshwater Quaternary fish fauna of the European part of the USSR.] Izdatel'stvo Moskovskogo universiteta, Moskva. (In Russian.)

Leciejewicz L., Rulewicz M., Wesołowski S., Wieczorowski T., 1972. La Ville de Szczecin des IX $^{\mathrm{e}}-\mathrm{XIII}{ }^{\mathrm{e}}$ siècles. Archaeologia Urbium, Pologne. Fasc. 2. Zakład Narodowy
Imienia Ossolińskich - Wydawnictwo Polskiej Akademii Nauk, Wrocław-Warszawa-Kraków-Gdańsk.

Makowiecki D., 1993. O możliwościach poznawczych i niektórych problemach metodycznych archeozoologii polskiej. [Cognitive potential and selected methodological problems of Polish archaeozoology.] Archeologia Polski 38 (1): 37-49. (In Polish.)

Makowiecki D., 2003. Historia ryb i rybołówstwa w Holocenie na Niżu Polskim w świetle badań archeoichtiologicznych. [History of fishes and fishing in Holocene on Polish Lowland in the light of archeoichthyological studies.] Instytut Archeologii i Etnologii Polskiej Akademii Nauk, Poznań. (In Polish.)

Marciniak A., 1996. Archeologia i jej źródła. Materiały faunistyczne w praktyce badawczej archeologii. [Archaeology and its sources. Faunistic materials in the practice of archaeological research.] Wydawnictwo Naukowe PAN, Warszawa-Poznań. (In Polish.)

Ninua N.Š., 1976. Atlantičeskij osetr reki Rioni. [Atlantic sturgeon of the Rioni River.] Izdatel'stvo Metsniereba, Tbilisi. (In Russian.)

Rolik W., Rembiszewski J.M., 1987. Ryby i kragłouste. [Fishes and cyclostomates.] PWN, Warszawa. (In Polish.)

Rulewicz M., 1974. Ze studiów nad rybołówstwem we wczesnośredniowiecznych miastach przy ujściu Odry. [A contribution to the knowledge on fishing in early medieval towns in the Odra River estuary.] Archeologia Polski 19 (2): 387-482. (In Polish.)

Rulewicz M., 1994. Rybołówstwo Gdańska na tle ośrodków miejskich Pomorza od IX do XIII wieku. [Fishing of the city of Gdańsk in relation to other urban centres of Pomerania from 9th to 13th century.] Ossolineum, Wrocław-Warszawa-Kraków. (In Polish.)

Suworow W.K. 1954. Podstawy ichtiologii. [Fundamentals of ichthyology.] PWN, Warszawa. (In Polish.)

Urbanowicz K., 1965. Połowy jesiotra zachodniego Acipenser sturio L. we wczesnośredniowiecznym Gdańsku w świetle materiałów wykopaliskowych. [Catches of the common sturgeon, Acipenser sturio L. in early medieval Gdańsk in view of the excavation material.] Przegląd Zoologiczny 9 (4): 372-377. (In Polish.)

Wesołowski S., 1963. Odkrycie łodzi słowiańskiej na podgrodziu w Szczecinie. [The discovery of a Slavic boat at the foot of the Szczecin castle.] Z otchłani wieków 29 (4): 254-258. (In Polish.)

Wieczorowski T., 1962. Najnowsze odkrycia archeologiczne na podgrodziu słowiańskim $\mathrm{w}$ Szczecinie. [The most recent archaeological discovery in the Slavic Szczecin settlement area at the foot of the castle.] Instytut Zachodnio-Pomorski (7-8): 179-184. (In Polish.)

Received: 14 October 2004 Accepted: 6 June 2005 